\title{
Hydrodynamic forcings and environmental impacts on the coast and shelf of São Bento do Norte - NE/Brazil
}

\author{
W. F. Tabosa ${ }^{1} \&$ H. Vital ${ }^{1,2}$ \\ ${ }^{1}$ Post Graduation Program on Geodynamics and Geophysics, Federal \\ University of Rio Grande do Norte State, PPGG/UFRN, Brazil \\ ${ }^{2}$ Department of Geology, UFRN - CNPq researcher, Brazil
}

\begin{abstract}
This work presents and discusses physical oceanographic data and seafloor morphology on the Northeast Brazilian coast and shelf adjacent to Sao Bento do Norte - Rio Grande do Norte State (RN). This shelf represents a modern, high dynamic mixed shelf system. It is inserted in the Potiguar Basin, which is the most productive oil and gas Brazilian basin onshore. Moreover, this entire coast is under severe erosion. Hydrodynamic and sediment dynamic processes reflect forcing by high waves, wind power, and mesotidal regime. This high-energy setting associated with mixed sedimentation supports the presence of highly variable seabed features (e.g. dunes, reefs and isolated sand bodies). The development of such great bedforms on the shelf reflects strong currents and tidal effects. The current speed values recorded occur within the interval $1,2 \leq|\vec{v}|$ $\geq 77,1 \mathrm{~cm} \cdot \mathrm{s}^{-1}$, with the main direction to the SW. The integration of these data allows the seabed characteristics to be related to the current pattern. This kind of information is very important to help contingency plans, to understand why erosion occurs in the São Bento area, and in conflict resolution (e.g. the oil industry, fishing, tourism). Moreover these datasets will also play a role in providing coastal zone managers with the coastal and ocean data they need to manage in a more informed manner.
\end{abstract}

Keywords: bedforms, tide- and wind-driven processes, coast changes, hydrodynamic forcings, environmental geology, inner shelf, northeast Brazil. 


\section{Introduction}

The Brazilian coastline extends for around 8,500 kilometers. It encloses 17 States, 405 cities and 16 metropolitans regions, concentrating more than $20 \%$ of the Brazilian population [1]. The presence of large and growing populations in the coastal zone creates major problems. More people in the coastal zones means more pollution of coastal waters, more pressure on nearby natural resources (for example, mangrove forests for firewood and beach sand for construction), and more pressure on fishery resources [2]. Brazil's northeastern coast and ocean have been utilized for port development, onshore and offshore oil production, tourism, urbanization, industrialization, scientific research, fisheries operations, and recreation. Moreover, coastal erosion is present in many parts of this coast. Heavy use of Brazilian coastal resources has placed enormous stress on the coastal environment, posing a number of challenges to coastal planning, management, and implementation [2]. Unless effective steps to manage these areas are taken soon, losses of considerable consequence will occur [2]. The protection of critical habitats, the necessity of maintenance of biodiversity and integrity of the sea communities to understand the local dynamics (condition hydrodynamics, meteorological, geomorphologic, etc), are basic conditions for an harmonious cohabit between man and the nature [1].

The aims of this study were to characterize the seabed morphology, to record hydrodynamic parameter (currents, tides, water temperature, conductivity), and establish the relation between tide- and wind-driven processes and their signature on the bottom morphology features in this hitherto unknown portion of the Brazilian equatorial inner shelf. According to [3], the inner shelf links the realms of the land margin to the mid and outer shelf and to the deep sea. Not only does it serve as a conduit for across-margin particulate transport, but it also modulates the hydrodynamic forcings that drive surf zone processes. This means, that, under most circumstances, the frictional effects of winds blowing over the sea surface are transmitted directly to the sea bed. It also means that the drag effects imparted on the flow by the morphology of the bed can extend all the way to the sea surface and thereby influence the flows that exist throughout the water column [3].

\subsection{Study area}

São Bento do Norte is on the north coast of Rio Grande do Norte State- NE Brazil, fig. 1. It is inserted in a coastal zone with about $15 \mathrm{~km}$ of sandy beaches, interrupted by beachrocks lines, aeolianites, dune fields and shell midden.

The coastal zone of Sao Bento do Norte is characterized as an unstable coast which reflects a dynamic regime, under morphological, structural and sedimentological changes, gradually recorded along time. These changes are directly linked to natural phenomena, and enhanced by anthropogenic intervention [5].

The climate of the study area is tropical hot, typical from semi-arid medium areas [6], and it is subjected to the instabilities of the Intertropical Convergence 
Zone (ITCZ). The area is defined by two weather seasons: a drought period from August to December, when the ITCZ moves away from the coast, creating the absence of rains and appearance of stronger winds; and a rainy season from May to July, which is associated with the southward displacement of ITCZ and the formation of softer winds. The annual rainfall rate of the area is quite irregular, ranging from $601 \mathrm{~mm} /$ year to $854 \mathrm{~mm} /$ year.

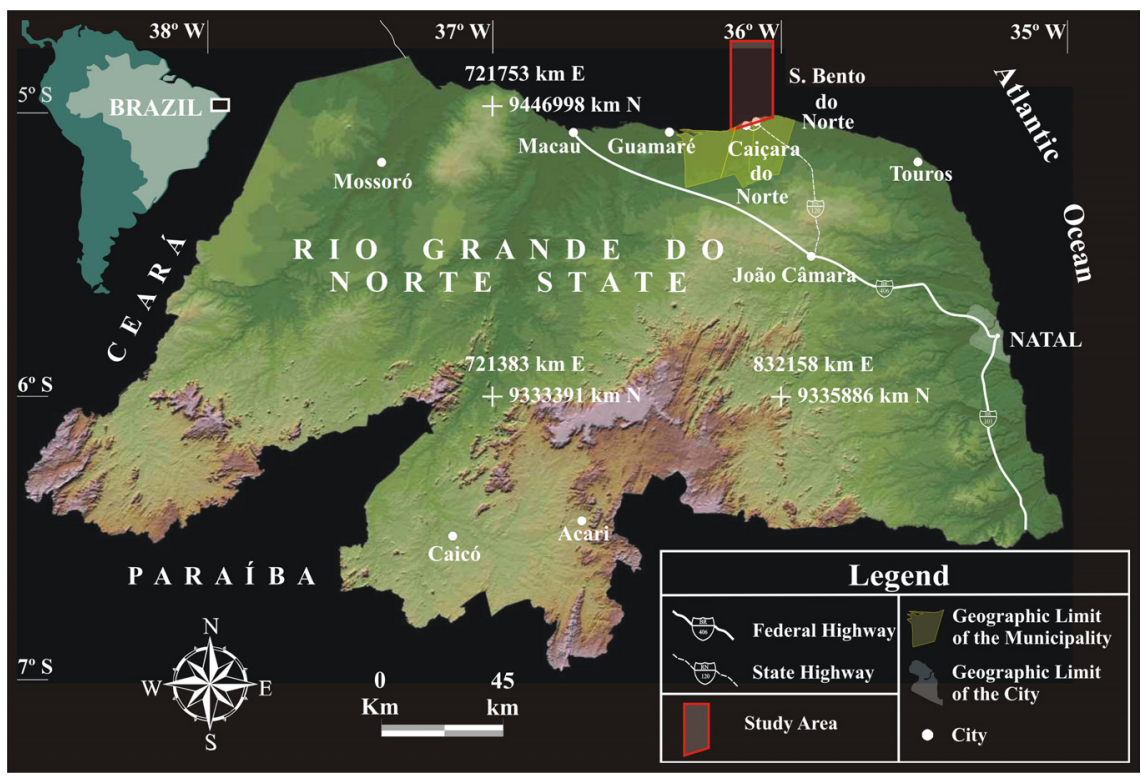

Figure 1: $\quad$ Location of the studied area. Modified from Miranda [4].

The wind direction presents two patterns in the study coast: from southeast between March-July and stronger from east-northeast between August-January. Statistical data shows that the winds of the area reach speeds in the order of 6.2 $\mathrm{m} / \mathrm{s}[7,8]$. The mean wind velocity in March is $4.8 \mathrm{~m} / \mathrm{s}$ while in October is 7.7 $\mathrm{m} / \mathrm{s}$ [9]. The south Atlantic anticyclone produces trade winds, which blow toward the Equator [10]. The seasonal migration of the Atlantic high-pressure cell together with the thermal heating of the continent force the trade winds to tangent the Brazilian coast. In the study area, moderate to storm winds induce temporary currents that can lead to the reversal of sediment transport direction and induced erosive processes on the seabed. In São Bento do Norte area, the annual average winds speed of the $6.17 \mathrm{~m} / \mathrm{s}$. The predominant direction of the winds oscillated between $\mathrm{N} 50^{\circ}$ and $\mathrm{N} 60^{\circ}$ [11].

The Brazilian shelf adjacent to São Bento do Norte is a shallow water continental shelf, where tidal currents are the main agents responsible for sediment dynamics. It is characterized by semi-diurnal tides and meso-tidal regimes. The mean spring tidal range from $0.2 \mathrm{~m}$ (low water) to $2.8 \mathrm{~m}$ (high water). It is also characterized by sea waves coming from the northeast direction, 
having a predominant plunging breaker and longshore currents of up to $85 \mathrm{~cm} . \mathrm{s}^{-1}$, which generates an intense coastal drift from east to west. In the offshore zone the sea waves are refracted by sandy bar and sandstone banks, which compose the sea bottom topography.

The Sao Bento do Norte beaches are classified as reflective to intermediate, and are under strong erosion. During last forty years beaches have retreat by 250 $\mathrm{m}$ on average [12].

\section{Methods}

A satellite image from 2000 (Landsat 7ETM+ from June 12, 00 at 10:00 a.m.) was employed. Three measuring stations were selected in order to examine the hydrodynamic forcing in the inner shelf, fig. 2. For the measurements, a "C/T/D Sensor 3231", a "Doppler Current Sensor 3500" both manufactured by Aanderaa Instruments, and two "S4" manufactured by Interocean were installed over 7 days, at $3 \mathrm{~m}$ and $7.5 \mathrm{~m}$ above seabed in March / 2004 and April /2005. The sampling interval at each station was $10 \mathrm{~min}$, fig. 2. Low neap conditions prevailed at the beginning and the end of the measurement period, while high spring conditions in the middle. Seabottom morphology was determined from bathymetric profiles. The applied echosounder system "Hydrotac" was manufactured by Odom Hydrographic Systems Inc connected to a DGPS. The acoustic signal had a frequency of $200 \mathrm{kHz}$. The investigated area was surveyed by 30 tracks with lengths of $25 \mathrm{~km}$ and spaced $1 \mathrm{~km}$ from each other fig 2 . A side scan sonar manufactured by EdgeTech was also used. The fieldwork was done using small fisher boat appropriated to operate in waters as shallow as 1.5 $\mathrm{m}$. In laboratory the data were processed using different software (e.g. WaveWin, S4 Application version 3.0.32 and Surfer8) before interpretation.

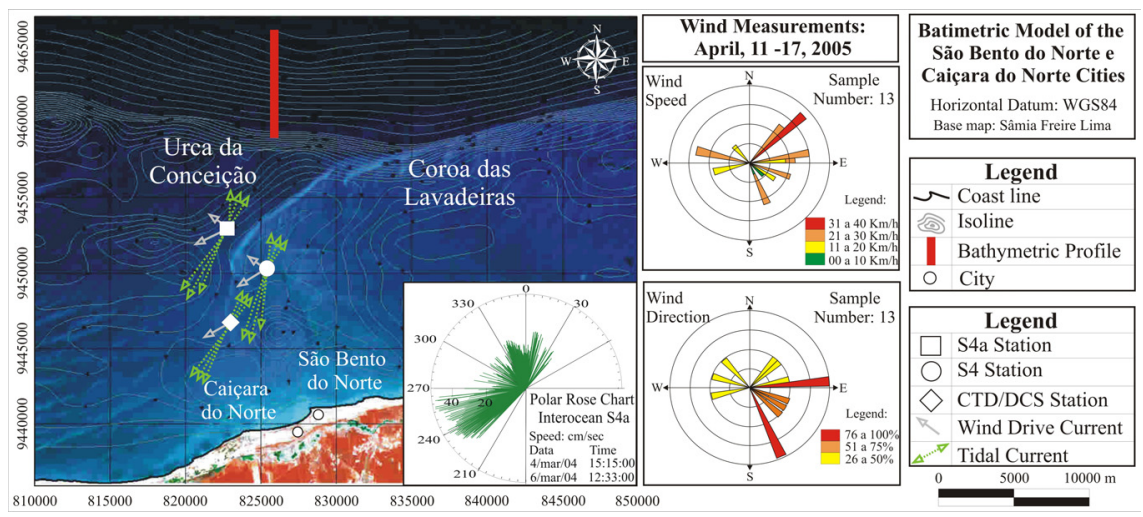

Figure 2: Schematic model of the Sao Bento do Norte shelf with location of the hydrodynamic stations and bathymetric isoline. 


\section{Results}

Results from current measurements are used to quantify the characteristics of hydro-sedimentary processes acting on seabed. Special attention has been paid to instantaneous and residual sediment transport caused by tidal currents, solely, and to combined tide- and wind-driven currents. The integration of morphologic data with in situ hydrodynamic measurements, and the digital processing of images allow the elaboration of a schematically model of the studied area.

\subsection{Coastal process}

\subsubsection{Currents}

The physical oceanographic data acquired in this study had registered uniformity in the direction and intensity of currents. The current speed values recorded occur within the interval $1.2-77.1 \mathrm{~cm} . \mathrm{s}^{-1}$. The vectors were more concentrated in southwest direction. However, a small variation for northwest was also observed. This current direction is suitable with the historical registers of the winds in the São Bento do Norte region $[8,11,13,14]$, and differs from the observed predominant direction in other areas to the west, as Guamaré, which flow preferentially for northwest $[15,16]$. In minor amounts, different current directions can also be observed (west, north and northeast). A bar diagram with the different intensities and directions of currents registered in the field are show in fig. 3 .

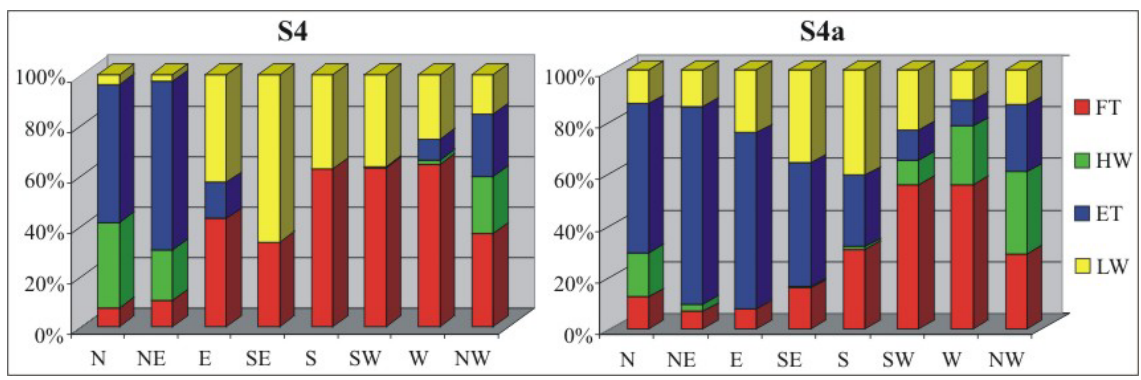

Figure 3: Diagrams showing the frequency and direction of the current vector according to the tides. FT - Flood Tide, HW - High Water, ET Ebb Tide and LW - Low Water.

\subsubsection{Currents and tides}

Directions of the current vector are also grouped in accordance with period of tides, fig.3. In the station where the S4a sensor was installed the currents present greater dispersion and intensity $\left(45 \mathrm{~cm} \cdot \mathrm{s}^{-1}, \mathrm{~N} 245^{\circ}\right)$, when compared with the stations of the S4 sensor $\left(23 \mathrm{~cm} \cdot \mathrm{s}^{-1}, \mathrm{~N} 220^{\circ}\right)$ and of CTD/DCS sensor $\left(13 \mathrm{~cm} . \mathrm{s}^{-1}\right.$, N257). Measurements recorded during Flood times (FT) showed a more effective current transport in a W/SW direction, while most Ebb current data (ET) indicated velocity vectors to the N/NE. 


\subsubsection{Conductivity, temperature and humidity}

The water temperature and conductivity presents minimum variations, $29.11^{\circ} \mathrm{C}$ to $29.47^{\circ} \mathrm{C}$, and 5.69 and $5.87 \mathrm{~S} / \mathrm{m}$, respectively, indicating mixture of the water masses. The atmospheric conditions in turn present significant variations. Temperature range from $31.7^{\circ} \mathrm{C}$ to $26.3^{\circ} \mathrm{C}$, humidity of the air from $96 \%$ to $88 \%$ during the morning and from $84 \%$ to $60 \%$ during the afternoon.

\subsection{The seabed morphology}

The side scan sonar profiles had shown the difference of texture in the diverse dominions of the seabed, caused mainly for the difference of composition of bottom substrate and by the bottom morphology. The echosound profiles had allowed the visualization of the seabed morphology, standing out the dimensions of the submerged bodies. The adjacent inner shelf of São Bento do Norte presents a variety of bedforms which range from kilometers to tens of centimeters in scale. The descriptive classification applied to the bedforms here is according to $[16,17]$. The most expressive are dunes fields, sandstone banks, and isolated sandy bodies.

\subsubsection{Dune fields}

The dune fields present on the area were separated in three groups: 1) 3D very large longitudinal asymmetric dunes - In general dune crest are oriented parallel to the coastline with E-W direction, and restricted to water depths shallower than $10 \mathrm{~m}$. Heights reach up to $6 \mathrm{~m}$, widths vary from $400 \mathrm{~m}$ to more than $900 \mathrm{~m}$. These bedforms are composed mainly of siliciclastic sands (carbonates $<30 \%$ ); 2) $3 \mathrm{D}$ very large transversal symmetrical dunes oriented NE-SW - Occur between 10 and $20 \mathrm{~m}$ depth, in a parallel strip limited landwards by dune fields from group 1 (about $10 \mathrm{~m}$ depth), and seawards by sandstone banks (about $20 \mathrm{~m}$ depth), and 3) 3D very large transversal asymmetrical dunes - located on the east side of the area, been limited seawards by the isolated shallow marine sand body (coroa das lavadeiras) with a complex external morphology composed of small dunes, which overlaps the larger ones. This $3^{\text {rd }}$ group has NE-SW direction. The transversal dunes (groups 2 and 3) display heights between 2 and $4 \mathrm{~m}$, width ranging from 100 to $500 \mathrm{~m}$; Biosiliciclastic sands (50-70\% carbonate) are the dominant component from $2^{\text {nd }}$ and $3^{\text {rd }}$ group. The diversity of the external morphology results from the variable combinations of tide- and wind-driven processes occurring in the study area. The asymmetry of tidal peak current velocity and the relative strength of wind-driven currents are the parameters that have the most important influence on dune architecture. Asymmetric large dunes with superposed small dunes result from a strong asymmetry in tidal peak current velocity, which is reversed only slightly during tidal movement and longshore drift.

\subsubsection{Sandstone banks}

Carbonatic buildups classified by Santos et al. [19], as sandstone bank (probably beachrocks) lined up parallel to the current shoreline also can be maps in the area. These sandstone banks are found in diverse points of the continental shelf 
of São Bento do Norte and Caiçara do Norte cities. Bathymetric and side scan sonar profiles indicate the presence of discontinuous elongated bodies, constituted of some sets of ten of kilometers in length. The bathymetric survey showed that the sea bottom morphology is relatively flat, with 2 to $6 \mathrm{~m}$ depth on the first $25 \mathrm{~km}$ of the inner shelf. Higher depths of the order of $20 \mathrm{~m}$ are registered around $30 \mathrm{~km}$ of the coast (fig 4). These deeper zones occur immediately after sandstone banks, called by the fisherman and registered in the nautical map of the Brazilian navy (Diretoria de Hidrografia e Navegação da Marinha do Brasil), as "Urca da Conceição". These features are probably related to old beachrocks.

\subsubsection{Isolated sand body}

A great scale bedform (or barform) according to Dalrymple and Rhodes [20], stand out in the portion far east of the area. It is emerged during low tides and called by the fishermen and in the nautical map of the Brazilian navy as "Coroa das Lavadeiras". It shows an elongated structure with a bending curve form at the west extremity. Echosound profiles and sediments samples from this bedform show that it is about 400 to $600 \mathrm{~m}$ width and asymmetrical with steep side facing seawards $[14,21]$. On the crest the sediments are mainly fine siliciclastic sands moderately to well-sorted, in contrast with the flanks. Seaward flanks contain bioclastic gravels, while landward flanks contain biosiliciclastic sands of medium sand size. Bodies of this type already had been described in literature as isolated shallow marine sand bodies [17, 20].

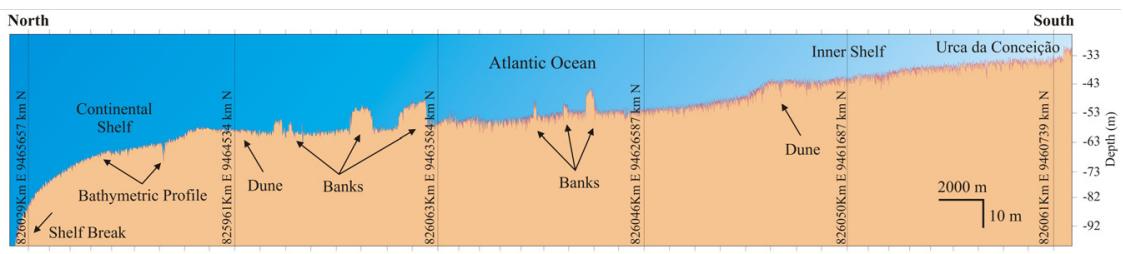

Figure 4: Example of bathymetric profile from São Bento do Norte continental shelf showing sandstone banks, dune and the shelf break.

\section{Conclusion}

The results of this study show that the presence of great bedforms on the inner shelf, represented by $3 \mathrm{D}$ very large longitudinal and transversal dunes, sandstone banks, and isolated shallow marine sand body. The current pattern in the São Bento do Norte shelf presents predominant direction to SW, different from the general pattern observed for other areas to the W (e.g. Guamaré) which is predominantly for NW. This pattern can be explained by the combination of two natural agents who interact simultaneously with oceanic waters: 1) The directional flow of coastal currents directly related to the distribution of the regional winds (coming from NE and SE), and 2) the bottom morphology. The 
presence of isolated shallow marine sand body (namely "Coroa das Lavadeiras") probably is a conditioning factor to this direction. Changes in the currents flow can be registered along the day, however, this variation are very little representative. The changes printed in the coastal zone and the inner shelf of São Bento do Norte area, are mainly conditioned by the coastal dynamics (mainly by the direct action of longshore drift and tides) and depth water.

\section{Acknowledgments}

This work was founded by the projects: PETRORISCO REDE 05/FINEP/CTPETRO), MAR-RN (FINEP/CTINFRA), PROBRAL (CAPES/DAAD 150/02) and CNPq (Proc. 500407/2004-5). The authors thank UFRN (GGEMMA/DG/PPGG) for the logistic support and ANP-PRH 22 (Petroleum National Agency), for the scholarship to the first author. Thanks are also due to everybody that participated in the fieldwork, and contributed with constructive criticism, discussions and bibliographical suggestions to the improvement of the present work.

\section{References}

[1] Garreta-Harkot, P.F. \& Alves, M.R.C., The Brazilian coastal zone: The main environmental problems and their consequences for human health: ISEE-425. Epidemiology. 14(5) supplement: S85-S86, 2003.

[2] Cicin-Sain, B. \& Knecht, R.W., Integrated coastal and ocean management, Island Press: Washington, DC, 517, 1998.

[3] Wright, L.D., Morphodynamics of inner continental shelves, CRC Press Inc: Boca Raton, 241p, 1995.

[4] Miranda, E.E. de, Brasil em Relevo. Campinas: Embrapa Monitoramento por Satélite, http://www.relevobr.cnpm.embrapa.br. 2005.

[5] Tabosa, W.F., Monitoramento Costeira das Praias de São Bento do Norte e Caiçara do Norte - RN: Implicações para o pólo petrolífero de Guamaré. Post Graduation Program on Geodynamics and Geophysics. Rio Grande do Norte Federal University, Master's Thesis, 112p, 2002.

[6] Nimer, E., Climatologia do Brasil. IBGE, Rio de Janeiro, 422p, 1989.

[7] Costa Neto, L.X., Evolução Geológica-Geomorfológica Recente da Plataforma Continental Interna ao Largo do Delta do Rio Açu, Macau $R N$. Marine Geology and Geophysics. Fluminense Federal University, Rio de Janeiro, Brazil. Master's Thesis, 234p, 1997.

[8] Tabosa, W.F., Dinâmica Costeira da Região de São Bento do Norte e Caiçara do Norte - RN. Department of Geology, Rio Grande do Norte Federal University, Graduation, 76p, 2000.

[9] Caldas, L.H.O., 2002. Late Quaternary Coastal Evolution of the Northern Rio Grande do Norte Coast, NE Brazil. Institute für Geowissenchaften, Christian-Albrechts-University Für Kiel, Germany. Ph.D. Thesis, 92p, 2002 . 
[10] Dominguez, J.M.L., Bittencourt, A.C. \& Martin, L., Controls on Quarternary coastal evolution of the east-northeastern coast of Brazil. Roles of sea-level history, trade winds and climate. Sedimentary Geology, Elsevier Science Publisher: Amsterdam, 80, pp. 213-232, 1992.

[11] Tabosa, W.F., Lima, Z.M.C., Vital, H., \& Guedes, I.M.G., Monitoramento costeiro das praias de São Bento do Norte e Caiçara do Norte - NE/Brasil. ABEQUA, VII Congresso da Associação Brasileira de Estudos do Quaternário, Instituto de Geociências da UFRG, Porto Alegre, RS, Brasil, Revista Pesquisas Em Geociências, 28(2), pp. 383-392, 2001.

[12] Vital, H., Stattegger, K., Amaro, V.E., Frazão, E.P. \& Tabosa, W.F., Seallevel change on the Brazilian Northeastern shelf. International Conference Mineral Deposits of Continental Shelves and 5th (final) annual Conference IGCP-464, Continental Shelves During Last Glacial Cycle. St. Petersburg, Russian, pp.111-113, 2005.

[13] Chaves, M.S., Vital, H. \& Silveira, I.M., Beach Morphodynamic of the Serra Oil Field, northeastern Brazil. Journal of Coastal Research, SI 39 (Proceedings of the 8th International Coastal Symposium), pg - pg. in press.

[14] Tabosa, W.F., Amaro, V.E. \& Vital, H., Análise do ambiente costeiro e marinho, a partir de produtos de sensoriamento remoto na região de São Bento do Norte, NE Brasil. Revista Brasileira de Geofísica. Rio de Janeiro. Submitted.

[15] Araújo, M, Silva, M.A., Frazão, E.P., Vital, H., Montagne, R. \& Araujo, R. Caracterização das forçantes dinâmicas - correntes, ondas e marés - na região costeira de Guamaré-RN, Brasil. Relatório Projeto Petrorisco. In press.

[16] Frazão, E.P., Estudo hidroacustico e hidrodinâmico da plataforma continental do Rio Grande do Norte: Sistemas Açu e Potengi. Post Graduation Program on Geodynamics and Geophysics. Rio Grande do Norte Federal University, Natal/RN, Brazil, 32p, 2005.

[17] Snedden, J.W. \& Dalrymple, R.W., Modern shelf sand ridges: From Historical perspective to a unified hydrodynamic and evolutionary model. Isolated Shallow Marine Sand Bodies: Sequence Stratigraphic Analysis And Sedimentologic Interpretation, eds. K.M. Bergman \& J.W. Snedden, Society for Sedimentary Geology, SEPM, Special Publication, 64, pp. 1328, 1999.

[18] Ashley, G.M, Classification of large-scale subaqueous Bedforms: A new look at an old Problem: Journal of Sedimentary Petrology, 60, pp. 160172. 1990.

[19] Santos C.L.A., Vital. H., Amaro V.E. \& Kikuchi, R.P., Mapping Submerged Reefs On The Rio Grande Do Norte Coast, Ne Brazil: Macau To Maracajau. Revista Brasileira de Geofisica. Rio de Janeiro. In press.

[20] Dalrymple, R.W. \& Rhodes, R.N., Estuarine dunes and barforms. Geomorphology and Sedimentology of Estuaries, ed. G.M Perillo, Sedimentology, Elsevier Science Publisher: Amsterdam, 53, pp. 359-422, 1995. 
174 Environmental Problems in Coastal Regions VI

[21] Vital, H., Stattegger. K., Amaro, V.E., Schwarzer, K., Frazão, E.P., Tabosa, W.F. \& Silveira, I.M., Inner Continental Shelf off Northern Rio Grande do Norte, NE Brazil: A modern high-energy siliciclastic-carbonate platform. Recent Advances in Shoreline-Shelf Stratigraphy, eds. G. Hampson \& R. Dalrymple, Society for Sedimentary Geology, SEPM, Special Publication, Submitted. 